TITLE:

\title{
The sexual behavior of Japanese monkeys(Abstract_要旨)
}

AUTHOR(S):

Enomoto, Tomoo

CITATION:

Enomoto, Tomoo. The sexual behavior of Japanese monkeys. 京都大学 , 1979, 理学博士

ISSUE DATE:

1979-07-23

URL:

http://hdl.handle.net/2433/222320

RIGHT: 


\section{【 $86 】$}

氏 名榎本 知 郎

学位の種類理学 博士

学位記番号論 理 博 第 656 号

学位授与の日付 昭 和 54 年 7 月 23 日

学位授与の要件 学 位 規則第 5 条第 2 項該 当

学位論文題目 The sexual behavior of Japanese monkeys

(ニホンザルの性行動)

論文調査委員教授日高敏隆教授池田次郎教授河合雅雄

\section{論文内容 の 要 旨}

申請論文は，ニホンザルの性行動について行動学的な分析を加えたものであり，血縁関係の明らかな志 賀 $\mathrm{A}$ 群が研究の主対象となっている。主論文 Part I では，交尾期に特徴的に見られる行動のすべてと， 交尾期に出現頻度が高くなる行動のすべてを性行動として扱い，46の行動パターンについての精密な記載 を行った。申請者は，これらの諸行動の記号性を検討しているが, hindquarters-display (HQD) という $6 つ$ 要素的行動の連鎖からなる行動は，そのあとに交尾の見られた率が74.1\%，交尾の前にこの行動が 見られた率は76.9\%という值によっても明らかなように，それが交尾と強く結びついた記号的行動であり， メスの恐怖を減殺するために発達した儀式的行動であるとしている。これと類似の記号性をむつものに, hand-on-back といら行動がある。各性行動の記載と分析についで, 性行動の各パターンの時間的な継起 をその出現頻度によって表わしながら，ニホンザルのもっとも一般的な性行動のあり方とそのヴァラェテ イーが図示されている。交尾の頻度についても検討が加兄られ，従来の研究結果とは異なり，オスの順位 と交尾回数との間には相関を認めえないことが示されている。メスの側からのオスの選択をとってみても, メスは必ずしも高順位のオスを交尾の対象として選択していない。同じ血縁集団に属する両性の間では, オスは積極的な行動を示すが，メスは消極的で，このメスの拒否的な態度によって同じ血縁内での交尾は 低い值にとどまっており，ニホンザル社会に括けるインセスト回避は，オスの出自群からの離脱だけでな く,メスの心理的な回避機構にもよっていることが明らかにされた。

主論文 Part II は，性的対象の選択をさらに掘り下げょうとしたもので，性的交涉の過程を８種類に分 け，これを指標として分析を和こなった。血縁関係にある両性の間では，37.5\%がともに消極的で射精を 伴ふず，伯父一姪，従兄妹間に正常な交尾が見られたにすぎない。非交尾期に諸種の親密な関係にあるぺ アも射精を伴わ交尾に終ることが多いのに対して, 交尾期にオスがメスを攻撃する関係では, 一般に正 常な交尾が見られた。申請者は, 以上の分析に基づいて, インセスト回避機構はこれらの社会関係と密接 な関係にあり，これまで問題にされてきた母－息子間の関係にとどまらず，より広い血縁的，親和的関係 にも同様の回避の傾向が見られること, メスの側の強い拒否による選択性が認められ，これがオスの群れ 
からの離脱にも関係しているにちがいないことを指摘した。

\section{論文審查の結果の要旨}

霊長類の性行動に関する分類は， C.R. Carpenter (1942) その他があるが，本申請論文に特いて提出 された類別と記載ほど詳細をきわめたものはかつてない。しかもその記述は的確ですぐれたものであり， 後進の研究者の利用に耐えるものを残したという点からしても得難い労作であるといってよい。申請者は, これらの諸行動の記号性について検討を加えているが，とくに， hindquarters-display という行動に着 目して，その発見とそれに伴って継起する交尾との関係について量的な分析を括こなっている。これは， ニホンザルの儀式的行動の一つに加えられた，見事な行動学的分析の一例であると言ってよいであるら。 このようにして分類され，それぞれに機能的な分類を行った46の性行動パターンに基づいて，性関係拉よ び性的交渉の対象選択についての分析が試みられている。その結果, 以下の二つの注目すべき結論が得ら れている。その一つは, 優位なオスほどより多くの交尾を行い, 自らの遺伝子をその群れに残す機会をよ り多くもつという, 従来支配的であった諸説に対する反論である。るう一つは, 社会構造との関連で, 長 く議論の焦点となっていたインセスト回避機構について, 現象的な解を見いだした点である。前者は, 社 会現象についての安易な機械論に対する批判を含んで和り, 後者は, 人間においてニニヴァーサル・カル チュアと呼ばれてきたインセスト・タブーの解明に一歩近づきえた業績として高く評価することができる。

以上の新知見のほか, 全体として, きわめて複雑な現象を堅実な方法で量的に解析していった研究態度 は見事であり，また，従来の行動類型にとらわれず，自らの正確な観察にもとづいて，行動パターンの類 別のメッシュをさらに微細にしてゆくことによって自らの研究を成功に導いているが，この点もとくに評 価してよい。

よって本論文は, 理学博士の学位論文として価值あるものと認める。 